\title{
Effect of propanol and dimethylsulphide in grass silage on organoleptic milk quality
}

\author{
Å.T. Randby ${ }^{1}$ \\ Norwegian University of Life Sciences, Department of Animal and Aquacultural Sciences \\ 1432 As, Norway
}

\begin{abstract}
Propanol (P) and dimethylsulphide (DMS) are two of many fermentation products that may be detected in small amounts in silage. When P alone, or together with DMS, was mixed into the silage before feeding, silage intake was slightly reduced but total DM intake was not affected. Both treatments reduced significantly the organoleptic quality of evening milk. This was mainly due to increased frequency of miscellaneous milk flavour. No significant difference in milk composition or taste was detected between cows fed P or P+DMS, suggesting that the milk taint was caused by propanol.
\end{abstract}

KEY WORDS: silage fermentation products, milk composition, taste, propanol

\section{INTRODUCTION}

Poorly fermented silage has long been assumed to reduce feed intake and to impart feed flavour to milk. Based on partial least square regression (PLSR) analysis of fermentation products detected in silage from problem herds, Mo et al. (2001) suggested that propanol (P) might reduce silage intake, and that dimethylsulphide (DMS) might cause milk taint.

Propanol may be formed in silage by yeasts or Clostridium bacteria through fermentation of threonine or methionine (Giudici et al., 1993; Janssen, 2004). Dimethylsulphide is a degradation product of methionine that is known to contribute both to the normal taste of milk, and to give off-flavour in high concentrations (Reddy et al., 1967). The effect of P and DMS in silage on intake by dairy cows and on milk composition was studied.

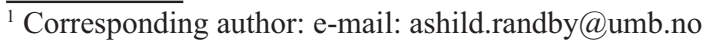




\section{MATERIAL AND METHODS}

In a cross over experiment with 30 high yielding Norwegian Red dairy cows with three 13-days periods, the addition of $200 \mathrm{~g}$ propanol daily, alone (P), or in combination with $4 \mathrm{~g}$ DMS (P+DMS) to the feed ration was studied. Because DMS could not be solved in water, but in alcohol, it was fed with P. The cows were given a control ration of well fermented regrowth grass silage ad libitum, containing $337 \mathrm{~g} / \mathrm{kg}$ DM, and per kg DM: $94 \mathrm{~g}$ crude protein (CP), $537 \mathrm{~g}$ NDF, $131 \mathrm{~g}$ total sugar, $27 \mathrm{~g}$ lacic acid, $13 \mathrm{~g}$ acetic acid, $2 \mathrm{~g}$ butyric acid and $6 \mathrm{~g}$ ethanol. A concentrate mixture (18\% CP in DM) based on barley $(30 \%)$, oats $(24.3 \%)$ wheat bran (14.1\%), soyabean meal (13.6\%), rape seed (5.7\%), fish meal (1\%), molasses $(7.9 \%)$ and minerals was fed at a fixed amount throughout, $8-12 \mathrm{~kg}$ daily, depending on block. The supplements of $\mathrm{P}$ and $\mathrm{P}+\mathrm{DMS}$ were mixed with silage during feeding. Silage was fed after morning milking, but before or during evening milking.

The feed analyses and milk analyses except $\mathrm{P}$ and DMS are described previously (Randby et al., 1999). To determine fatty acid composition, milk samples were dried at $20^{\circ} \mathrm{C}$ before methylation of the fatty acids (Ulberth and Henninger, 1992). The fatty acid composition was analysed using GC with a BPX-70 column (SGE Int. Pty Ltd., Ringwood Vic, Australia).

Unpreserved milk samples that were stored at $4^{\circ} \mathrm{C}$ for $48 \mathrm{~h}$ prior to being raised to $20^{\circ} \mathrm{C}$ were judged for taste and aroma by a sensory panel of three persons at the Norwegian Institute for Food and Environmental Analyses (Oslo). Scores for taste and aroma were evaluated on a five-point scale (where $1=$ poor quality milk with serious deviations from normal aroma or taste to $5=$ high quality milk with no deviation from normal aroma or taste). For samples scored at 3.5 or lower, the type of off flavour (i.e. lipolyzed, oxidized, transmitted, acid, miscellaneous) was indicated as described by Shipe et al. (1978). Some milk samples received more than one type of off flavour scoring.

Propanol and DMS in milk was analysed using headspace GC with a HPInnowax column and FID detector.

\section{RESULTS}

Silage DM intake was slightly reduced when $\mathrm{P}$ or $\mathrm{P}+\mathrm{DMS}$ was fed. The reduced intake equalled the amount of applied propanol, so that no reduction in total DM intake was detected (Table 1). Milk yield was similar for all groups, but due to reduced fat and protein concentrations in the milk, cows fed $\mathrm{P}$ or $\mathrm{P}+\mathrm{DMS}$ yielded slightly less energy corrected milk (Table 2). 
Table 1. Intake of silage, concentrates and added propanol (P) and dimethylsulphide (DMS); $\mathrm{n}=30$

\begin{tabular}{lccccc}
\hline Item & Control diet & P diet & P + DMS diet & SEM & P \\
\hline Silage DM, kg & $11.27^{\mathrm{a}}$ & $10.98^{\mathrm{b}}$ & $11.04^{\mathrm{b}}$ & 0.061 & 0.004 \\
Silage DM g/kg BW & $20.2^{\mathrm{a}}$ & $19.7^{\mathrm{b}}$ & $19.8^{\mathrm{b}}$ & 0.10 & 0.002 \\
Concentrate DM, kg & 8.56 & 8.57 & 8.56 & & \\
Propanol, g & 0 & 187 & 188 & & \\
Dimethylsulphide, g & 0 & 0 & 3.75 & & \\
Total DM, kg & 19.83 & 19.74 & 19.78 & 0.061 & $\mathrm{NS}$ \\
Total DM, g/kg BW & 35.5 & 35.4 & 35.4 & 0.10 & $\mathrm{NS}$ \\
\hline
\end{tabular}

Table 2. Daily milk yield, and composition of morning and evening milk; $n=30$

\begin{tabular}{|c|c|c|c|c|c|}
\hline Item & Control diet & $\mathrm{P}$ diet & $\mathrm{P}+\mathrm{DMS}$ diet & SEM & $\mathrm{P}$ \\
\hline \multicolumn{6}{|l|}{ Daily milk yield } \\
\hline milk, kg & 27.3 & 27.2 & 27.5 & 0.143 & NS \\
\hline ECM, kg & $27.6^{\mathrm{a}}$ & $27.1^{\mathrm{b}}$ & $27.4^{\mathrm{ab}}$ & 0.144 & 0.02 \\
\hline milk fat $\%$ & $4.18^{\mathrm{a}}$ & $4.07^{\mathrm{b}}$ & $4.07^{\mathrm{b}}$ & 0.020 & $<0.001$ \\
\hline milk protein $\%$ & $3.29^{\mathrm{a}}$ & $3.24^{\mathrm{b}}$ & $3.26^{\mathrm{b}}$ & 0.008 & $<0.001$ \\
\hline lactose $\%$ & 4.52 & 4.54 & 4.55 & 0.008 & 0.08 \\
\hline milk fat, $\mathrm{g}$ & $1139^{a}$ & $1104^{b}$ & $1115^{\mathrm{b}}$ & 6.8 & 0.003 \\
\hline milk protein, $g$ & $897^{\mathrm{a}}$ & $879^{\mathrm{b}}$ & $895^{b}$ & 4.7 & 0.02 \\
\hline lactose, $\mathrm{g}$ & 1236 & 1233 & 1249 & 7.6 & NS \\
\hline \multicolumn{6}{|l|}{ Morning milk } \\
\hline organoleptic quality $^{1}$ & 4.01 & 3.91 & 3.92 & 0.104 & NS \\
\hline urea, $\mathrm{mM}$ & 2.56 & 2.57 & 2.55 & 0.044 & NS \\
\hline acetone, $\mathrm{mM}$ & $0.031^{\mathrm{a}}$ & $0.026^{\mathrm{b}}$ & $0.025^{b}$ & 0.001 & 0.01 \\
\hline \multicolumn{6}{|l|}{ Evening milk } \\
\hline organoleptic quality ${ }^{1}$ & $3.54^{\mathrm{a}}$ & $3.19^{\mathrm{b}}$ & $3.05^{b}$ & 0.112 & 0.01 \\
\hline FFA, meq/l & 0.90 & 0.92 & 0.85 & 0.022 & 0.08 \\
\hline urea, mM & 2.43 & 2.47 & 2.41 & 0.039 & NS \\
\hline acetone, $\mathrm{mM}$ & $0.057^{\mathrm{a}}$ & $0.049^{\mathrm{b}}$ & $0.047^{\mathrm{b}}$ & 0.002 & $<0.001$ \\
\hline propanol, $\mathrm{ng} / \mathrm{ml}$ & $329^{a}$ & $1319^{\mathrm{b}}$ & $1183^{b}$ & 164 & $<0.001$ \\
\hline dimethylsulphide, $\mathrm{ng} / \mathrm{ml}$ & $45.7^{\mathrm{a}}$ & $41.8^{\mathrm{a}}$ & $119.5^{\mathrm{b}}$ & 24.6 & 0.048 \\
\hline
\end{tabular}

${ }^{1}$ five-point scale where 1 = poor quality milk with serious deviations from normal aroma or taste and $5=$ high quality milk with no deviation from normal aroma or taste

Although milk acetone concentrations were low, the two studied treatments reduced the levels further. Neither of the treatments influenced the organoleptic quality of morning milk, but both treatments reduced significantly the organoleptic quality of evening milk compared with control milk. This was mainly due to increased frequency of miscellaneous milk flavour, but increased frequency of malty, feed flavoured and lipolyzed milk also contributed to the reduced quality (Table 3). No significant difference in milk composition or taste was detected between cows fed $\mathrm{P}$ or $\mathrm{P}+\mathrm{DMS}$. 
Table 3. Percentage of samples assigned to the different categories of off-flavour in milk. Number of samples is presented in parentheses; $\mathrm{n}=30$

\begin{tabular}{lccccc}
\hline Item & Control diet $^{1}$ & P diet & P + DMS diet & $\chi^{2}$ & $\mathrm{P}$ \\
\hline Morning milk & & & & & \\
$\quad$ lipolyzed & $3.3(1)$ & $0.0(0)$ & $3.3(1)$ & 1.0 & $\mathrm{NS}$ \\
oxidized & $6.7(2)$ & $6.7(2)$ & $6.7(2)$ & 0.0 & $\mathrm{NS}$ \\
feed flavour & $0.0(0)$ & $0.0(0)$ & $3.3(1)$ & 2.0 & $\mathrm{NS}$ \\
malty/acidic & $10.0(3)$ & $16.7(5)$ & $10.0(3)$ & 0.8 & $\mathrm{NS}$ \\
miscellaneous & $6.7(2)$ & $13.3(4)$ & $10.0(3)$ & 0.7 & $\mathrm{NS}$ \\
all categories & $16.7(5)$ & $26.7(8)$ & $26.7(8)$ & 1.1 & $\mathrm{NS}$ \\
& & & & & \\
Evening milk & & & & & \\
lipolyzed & $6.9(2)$ & $10.0(3)$ & $13.3(4)$ & 0.7 & $\mathrm{NS}$ \\
oxidized & $10.3(3)$ & $3.3(1)$ & $3.3(1)$ & 1.8 & $\mathrm{NS}$ \\
feed flavour & $31.0(9)$ & $40.0(12)$ & $43.0(13)$ & 1.0 & $\mathrm{NS}$ \\
malty/acidic & $3.4(1)$ & $16.7(5)$ & $20.0(6)$ & 3.9 & $\mathrm{NS}$ \\
miscellaneous & $13.8(4)$ & $43.3(13)$ & $36.7(11)$ & 6.5 & 0.04 \\
all categories & $41.4(12)$ & $76.7(23)$ & $83.3(25)$ & 13.6 & 0.001 \\
\hline
\end{tabular}

${ }^{1}$ evening milk from cows fed control diet: $\mathrm{n}=29$

The proportions of C10:0, C12:0 and C15:0 fatty acids increased slightly, whereas the proportions of $\mathrm{C} 18: 0$ and $\mathrm{C} 18: 1$ trans 11 were slightly reduced when cows were fed P or P+DMS (Table 4).

Table 4. Fatty acid composition ${ }^{1}$ of evening milk, $g / 100 \mathrm{~g}$ total fatty acids; $\mathrm{n}=30$

\begin{tabular}{lccccc}
\hline Fatty acid & Control diet $^{1}$ & P diet & P + DMS diet & SEM & P \\
\hline C4:0 & 3.49 & 3.46 & 3.43 & 0.065 & NS \\
C6:0 & 2.54 & 2.52 & 2.57 & 0.024 & NS \\
C8:0 & 1.68 & 1.69 & 1.72 & 0.014 & 0.07 \\
C10:0 & $3.82^{\mathrm{a}}$ & $3.92^{\mathrm{b}}$ & $3.98^{\mathrm{b}}$ & 0.035 & 0.005 \\
C12:0 & $4.31^{\mathrm{a}}$ & $4.45^{\mathrm{b}}$ & $4.52^{\mathrm{b}}$ & 0.051 & 0.02 \\
C14:0 & 13.09 & 13.04 & 13.14 & 0.145 & $\mathrm{NS}$ \\
C14:1 & 1.04 & 1.07 & 1.09 & 0.020 & $\mathrm{NS}$ \\
C15:0 & $0.97^{\mathrm{a}}$ & $1.12^{\mathrm{b}}$ & $1.12^{\mathrm{b}}$ & 0.018 & $<0.001$ \\
C16:0 & 26.9 & 26.9 & 26.9 & 0.345 & $\mathrm{NS}$ \\
C16:1 & 1.28 & 1.28 & 1.30 & 0.021 & $\mathrm{NS}$ \\
C18:0 & $11.00^{\mathrm{a}}$ & $10.72^{\mathrm{ab}}$ & $10.46^{\mathrm{b}}$ & 0.133 & 0.02 \\
C18:1, trans-11 & 1.22 & 1.13 & 1.09 & 0.037 & 0.05 \\
C18:1, cis-9 & 16.2 & 16.2 & 16.2 & 0.131 & $\mathrm{NS}$ \\
C18:2, cis-9,12, n-6 & 1.23 & 1.23 & 1.25 & 0.020 & $\mathrm{NS}$ \\
C18:2, cis-9, trans 11, CLA & 0.51 & 0.48 & 0.49 & 0.010 & $\mathrm{NS}$ \\
C18:3, cis-9,12,15, n-3 & 0.40 & 0.38 & 0.39 & 0.012 & $\mathrm{NS}$ \\
\hline
\end{tabular}

${ }^{1}$ proportion of total fatty acids ranging from $\mathrm{C} 4$ to $\mathrm{C} 22$ 


\section{DISCUSSION}

Steen et al. (1998) analysed propanol in samples from 136 grass silages with a wide variation in quality. Average and maximum concentration was 0.44 and $2.17 \%$ in DM, respectively. These values indicated that the daily dose of propanol from silage could reach $200 \mathrm{~g}$, which was chosen for the present study. Mo et al. (2001) detected DMS in 33 out of 84 silage samples. The average concentration in the samples where it was detected was $0.0018 \%$ (of wet weight), with a maximum value of $0.0070 \%(0.0157 \%$ in DM). This suggested that the maximum daily intake of DMS from silage could be approx. $2 \mathrm{~g}$. The daily dose of $4 \mathrm{~g}(64 \mathrm{mM})$ that was chosen for this study was also based on the amount of methionine $(157 \mathrm{mM})$ that have induced milk taint when fed (Dunham et al., 1968), or that have given intoxication when infused into the rumen $(600 \mathrm{mM})$ (Velle et al., 1997), or that could be infused into the rumen with no symtoms of intoxication (335 and $300 \mathrm{mM}$ ) (Emery, 1971; Velle et al., 1997).

Silage DM intake, and consequently total NDF intake, by cows was reduced when cows were fed propanol, although total DM intake was not affected. This was in contrast to a previous study with ethanol (Randby et al., 1999). Feeding of $600 \mathrm{~g}$ ethanol daily did not alter silage intake, but increased total DM intake.

Propanol decreased fat, protein and acetone concentrations and increased slightly lactose concentration in milk, all of which was opposite to the previously reported effect of ethanol. Although the effect of the two alcohols on milk composition was contrasting, their negative effect on the organoleptic milk quality was similar. This suggests that the chain length of the molecules (C3 vs $\mathrm{C} 2)$ is responsible for the glucogenic vs lipogenic effect, whereas the alcohol group is responsible for the reduced taste quality of milk. The metabolites from alcohol degradation that taint milk shortly after alcohol ingestion must be further metabolized within few $\mathrm{h}$, because off flavour was not detected in morning milk.

The effect of propanol on milk fatty acid composition was small and not related to the effect of ethanol on fatty acid composition. Although no significant effect of DMS was elucidated in this study, a possible effect on milk flavour cannot be excluded. In the present study, the effect of DMS may have been masked by the effect of propanol.

\section{CONCLUSIONS}

Propanol in feed reduced silage DM intake slightly, but did not influence total DM intake. Propanol reduced the organoleptic quality of evening milk. Similar results are previously found for ethanol, which suggest that alcohol containing feed in general reduces the taste of milk. The quality reduction may be avoided if 
the alcohol containing feed is fed after, rather than before milking. No significant effect on intake or milk quality was found of dimethylsulphide when it was fed together with propanol.

\section{REFERENCES}

Dunham J.R., Ward G., Basette R., Reddy M.C., 1968. Methionine as a precursor of methyl sulfide in cows' milk. J. Dairy Sci. 51, 199-201

Emery R.S., 1971. Disappearance of methionine from the rumen. J. Dairy Sci. 54, 1090-1091

Giudici P., Zambonelli C., Kunkee R.E., 1993. Increased production of $n$-propanol in wine by yeast strains having an impaired ability to form hydrogen sulfide. Amer. J. Enol. Viticult. 44, 17-21

Janssen P., 2004. Propanol as an end product of threonine fermentation. Arch. Microbiol. 182, 482486

Mo M., Selmer-Olsen I., Randby Å.T., Aakre S.E., Asmyhr A., 2001. "New” fermentation products in grass silage and their effects on feed intake and milk taste. Conference Proceedings: $10^{\text {th }}$ International Symposium on Forage Conservation. Brno (Czech Republic), pp. 98-99

Randby Å.T., Selmer-Olsen I., Baevre L., 1999. Effect of ethanol in feed on milk flavor and chemical composition. J. Dairy Sci. 82, 420-428

Reddy M.C., Bassette R., Ward G., Dunham J.R., 1967. Relationship of methyl sulfide and flavor score of milk. J. Dairy Sci. 50, 147-150

Shipe W.F., Bassette R., Deane D.D., Dunkley W.L., Hammond E.G., Harper W.J., Kleyn D.H., Morgan M.E., Nelson J.H., Scanlan R.A., 1978. Off flavors of milk: nomenclature, standards, and bibliography. J. Dairy Sci. 61, 855-869

Steen R.W.J., Gordon F.J., Dawson L.E.R., Park R.S., Mayne C.S., Agnew R.E., Kilpatrick D.J., Porter M.G., 1998. Factors affecting the intake of grass silage by cattle and prediction of silage intake. Anim. Sci. 66, 115-127

Ulberth F., Henninger M., 1992. One-step extraction/methylation method for determining the fatty acid composition of processed foods. J. AOCS 69, 174-177

Velle W., Sjaastad Ø.V., Aulie A., Grønseth D., Feigenwinter K., Framstad T., 1997. Rumen escape and apparent degradation of amino acids after individual intraruminal administration to cows.

J. Dairy Sci. 80, 3325-3332 